\title{
0 Ensino Religioso em Portugal e França: contribuições à reflexão e prática brasileira
}

\author{
Religious Education in Portugal and France: \\ contributions to reflection and practice in Brazil
}

\section{Claudio Santana Pimentel}

Doutorando e Mestre em Ciências da Religião pela Pontifícia Universidade Católica de São Paulo (PUC- SP), Bolsista da CAPES, São Paulo, SP - Brasil, e-mail: pimentelclaudio@live.com

\section{Resumo}

Este artigo pretende apresentar alguns aspectos da reflexão e prática internacional sobre o Ensino Religioso, ao expor e discutir o estado da questão em Portugal e França. A partir disso, pretende demonstrar como essa reflexão e prática abrem caminho para a constituição de um novo paradigma para o Ensino Religioso, paradigma que tem por base epistemológica a Ciência da Religião, afastando-se desse modo da compreensão tradicional que considera o Ensino Religioso uma disciplina confessional ou ecumênica, e que, portanto, deveria se restringir às instituições de ensino confessionais. Por fim, pretende-se aproximar a discussão internacional sobre o Ensino Religioso daquela que se está realizando no Brasil, para se perceber suas diferenças e seus pontos de contato.

Palavras-chave: Educação. Ensino Religioso. Ciência da Religião. 


\section{Abstract}

This article aims to present some aspects of the international reflection and practice on Religious Education by exposing and discussing the state of matter in Portugal and France. Based on that, it intends to show how those discussion and practices indicate the formation of a new paradigm to Religious Education, a paradigm epistemologically based in the Science of Religion, moving away from the traditional concept of Religious Education as confessional or ecumenist subject, that would thus be restricted to religiously affiliated educational institutions. Finally, it aims to approach the international discussion about Religious Education and the ongoing Brazilian debate, to understand differences and contact points.

Keywords: Education. Religious Education. Science of Religion.

\section{Introdução}

A discussão sobre o Ensino Religioso, e como este deve (ou não) ser incluído nas escolas, públicas principalmente, continua em andamento em nosso país. Este trabalho procura observar a discussão que está ocorrendo internacionalmente, voltando-se para Portugal e França, escolhidos graças a inúmeras aproximações culturais, políticas e históricas que podem ser feitas entre esses países e o Brasil. Consideramos que a definição do papel do Ensino Religioso na escola (pública) se insere em algo muito maior, que é a própria definição da formação que se deve e se quer oferecer aos estudantes. Tendo este pressuposto por base, procuraremos demonstrar, ao aproximarmos as situações desses três países, que estão sendo formadas as condições para um Ensino Religioso que possa atender as necessidades de uma escola laica e de uma sociedade plural.

\section{Ensino Religioso: perspectivas internacionais}

Nas duas próximas seções, exporemos a situação teórica e prática em que se encontra o ensino religioso em dois países europeus: França e 
Portugal. É importante atentar para o desenvolvimento histórico das relações dessas duas repúblicas com a religião; a história da república francesa mostra-se como o próprio paradigma da secularização, a religião sendo relegada para a vida privada, que, no decorrer da Idade Média e no início da Modernidade era a grande organizadora da vida social e política, não apenas francesa, mas ocidental (GAUCHET, 1998); em Portugal, percebe-se, no decorrer de sua história, uma ambiguidade das relações entre o Estado e a Igreja Católica. Se esta foi, no período monárquico e mesmo ainda no republicano, um importante apoio para quem estava no poder, essa relação não deixou de ser marcada por conflitos (PINTO, 2005, p. 2742), dos quais, o mais conhecido para nós, brasileiros, culminou com a expulsão da Companhia de Jesus pelo Marquês de Pombal no século XVIII. Por outro lado, enquanto a França se afirmou como uma república laica, deixando, portanto, a opção religiosa ser uma questão de foro íntimo de seus cidadãos, Portugal, mesmo tendo diminuído os espaços de poder da Igreja Católica, parece nunca ter deixado de se identificar como um país católico. A própria legislação conservou, durante muito tempo, o conceito jurídico de "religião da tradição" para se referir ao catolicismo romano. O questionamento sobre o lugar do ensino religioso nesses dois países (e, pode-se antecipar, não apenas neles) se configura a partir da seguinte indagação: qual a contribuição, considerando-se a organização laica e secular da sociedade, do ensino religioso para a formação do cidadão?

\section{Portugal: da religião da tradição à diversidade religiosa; do ensino religioso ao ensino das religiões}

As reflexões desta seção baseiam-se, principalmente, no livro de Paulo Mendes Pinto, Para uma Ciência das Religiões em Portugal (PINTO, 2005). Nele o autor parte, principalmente, da iniciativa da Universidade Lusófona de Humanidades e Tecnologias (Portugal), a primeira a oferecer, naquele país, uma licenciatura em Ciência das Religiões ${ }^{1}$. O livro,

1 A proposta do curso de licenciatura em Ciências das Religiões é explicitada por PINTO, P. M. Para uma ciência das religiões em Portugal: cidadania \& cultura. Lisboa: Universitárias Lusófonas, 2005. p. 107-112. A matriz 
num certo sentido, programático, pretende defender a necessidade desta "nova" disciplina, não apenas na vida universitária portuguesa, mas também na educação básica. Assim, Pinto pretende justificar a modificação da atual perspectiva de ensino religioso existente em seu país, que explicitaremos adiante, colocando a Ciência das Religiões como base de uma disciplina reformulada, que passaria a ser chamada, conforme a proposta do autor, "História das Religiões". Antes, convém acompanhar como se deu o desenvolvimento da questão do ensino religioso em Portugal.

Encontramos o Cristianismo, e, particularmente, o catolicismo romano, como elemento constituidor da identidade nacional portuguesa; o catolicismo mostrou-se fundamental para a consolidação cultural e política de Portugal, sobretudo em oposição ao Judaísmo e ao Islã (PINTO, 2005, p. 21-27). Assim, mesmo com a república, e a partir daí a diminuição da importância e do peso político da Igreja Católica na vida pública portuguesa, o Catolicismo se manteve presente, inclusive na legislação, como "religião da tradição" (PINTO, 2005, p. 34-38). Não apenas a religião que deu "forma" à nação, mas permanecendo reconhecida como a religião da maioria dos portugueses. No entanto, nas últimas décadas, algo mudou: a chegada de imigrantes de diversas regiões do mundo, sul-americanos (brasileiros, principalmente), africanos, europeus do leste e asiáticos, torna cada vez mais diversa a configuração social portuguesa; porém a organização escolar portuguesa ainda não acompanha esta nova dinâmica sociocultural (PINTO, 2005, p. 14-21).

Para compreendermos essa aparente defasagem entre a diversidade religiosa que cada vez mais está presente na sociedade portuguesa, e o tratamento legal e prático dado ao Ensino Religioso, temos que considerar que o desenvolvimento da conceptualização de religião presente na legislação de Portugal quase sempre esteve de alguma maneira, referido ao Catolicismo. Vejam-se os textos constitucionais de 1933 e 1971 (correspondendo ao início e ao fim do período salazarista), que fundamentavam a formação moral dos estudantes na tradição religiosa católica. A legislação de 1971 afirmava explicitamente ser o Catolicismo romano a

curricular atual e outras informações sobre o curso podem ser consultadas no sítio da Universidade Lusófona de Humanidades e Tecnologias. Disponível em: <www.ulusofona.pt>. Acesso em: 25 out. 2001. 
religião da nação portuguesa ${ }^{2}$ (PINTO, 2005, p. 34-38); o estatuto atual da religião e do ensino religioso em Portugal é dado pela Constituição de 1976 e pela legislação dela decorrente.

A Constituição de 1976 transformou profundamente o estatuto da questão religiosa na legislação portuguesa. O primeiro ponto a ser destacado é não fazer referência a qualquer religião em particular, como as legislações anteriores referiam-se explicitamente ao Cristianismo, conferindo ao Catolicismo Romano um lugar privilegiado na sociedade portuguesa e à Igreja Católica um estatuto particular nas relações com o Estado. O artigo $41^{\circ}$, dedicado às garantias de liberdade de consciência, religião e culto, explicita a liberdade religiosa, a proibição de qualquer tipo de perseguição ou discriminação fundamentada em razões religiosas, a separação entre as religiões e o Estado, a liberdade de ensino de qualquer religião e do uso dos meios de comunicação para sua divulgação, entre outros aspectos; já o artigo $43^{\circ}$, sobre a educação, excluía da educação pública qualquer diretriz religiosa, e proibia ao ensino público ser confessional (PINTO, 2005, p. 38-40).

Desse modo, a Constituição de 1976 demarcava claramente as relações entre Estado e religião, proibindo ao primeiro qualquer tipo de posicionamento religioso e excluindo da organização escolar qualquer referência à doutrina católica. Na constituição pós-revolucionária, a religião era considerada um assunto privado, podendo ser livremente ensinada e divulgada, mas não tendo abrigo no sistema educacional do Estado. A situação se modificaria mais uma vez quando, em 1987, o Tribunal Constitucional decidiu sobre a inconstitucionalidade do Decreto-Lei n. 323/83 que havia reintroduzido o ensino, nas instituições públicas, da religião e moral católicas. No entanto a decisão na prática não vetava o Ensino Religioso, porque considerava o referido decreto-lei inconstitucional apenas na medida em que este previa somente o ensino da religião e moral católicas, não incluindo as demais religiões. Assim, introduziu-se a situação atual em que se encontra o ensino religioso em Portugal: cabe ao Estado oferecer ao estudante, de

2 Mesmo a Constituição de 1911, a primeira constituição republicana de Portugal, embora afirmasse a liberdade de consciência e crença, submetesse as manifestações religiosas públicas à autoridade do Estado, e vetasse o Ensino Religioso nas escolas, considerava como religião prioritariamente o catolicismo, o que ficava evidente na proibição "perpétua" às atividades de ordens e congregações religiosas, explicitamente da Companhia de Jesus (PINTO, 2005, p. 33-34). 
acordo com a orientação religiosa declarada por este ou por seus responsáveis, sendo facultativa a frequência. É dizer, a religião continua sendo um assunto privado, mas o Estado provê o seu ensino. A indicação de professores para essa disciplina, tal como os conteúdos ministrados, são de responsabilidade das instituições religiosas (PINTO, 2005, p. 38-41, 46-49).

A proposta de Pinto parte da reconsideração do estatuto do ensino religioso nas escolas públicas portuguesas. Ao invés de prover um ensino de viés confessional, privado, que se oferece, contraditoriamente, sob o abrigo do Estado (PINTO, 2005, p. 43-44), propõe-se a substituição da disciplina de ensino religioso por outra, o ensino das religiões (PINTO, 2005, p. 49-50). Esta não seria mais, portanto, um apêndice estranho ao currículo escolar, mas seria integrado a este, por partir do pressuposto da diversidade cultural e religiosa que caracterizam Portugal e a Europa, por considerar a necessidade de conhecimento sobre as religiões - e não apenas sobre a própria opção religiosa - para a formação intelectual e cidadã dos estudantes portugueses. Mais importante do que a posição atual, que se restringe a conceder às instituições religiosas o espaço para promover a formação religiosa de seus próprios adeptos, é oferecer a todos, crentes e não crentes, o conhecimento a respeito do lugar que as religiões ocupam na sociedade e das relações que estabelecem com os diferentes atores sociais:

o essencial da questão da relação das crenças com o Estado e, em especial, com a escola, não se esgota aqui, no lugar, no espaço, no tempo de antena, que uma das partes faculta às outras. Antes pelo contrário, a concessão de um espaço específico para as confissões escamoteia, esquece, o fulcro da questão: a religião não é (só) coisa das confissões. A religião enquanto atividade social é um assunto de todos os cidadãos, do todo que são as diversas partes que constituem o Estado e os seus membros, religiosos ou não (PINTO, 2005, p. 44).

Se a própria escola priva o estudante, religioso ou não, do conhecimento social e politicamente necessário sobre as religiões - pois o máximo que lhe é oferecido é a autoimagem de sua própria filiação religiosa:

essa prática em nada contribui para uma integração social das vivências religiosas alheias e em nada concorrem para uma efetiva cultura de abertura: havendo uma matriz religiosa de base em todas as disciplinas de 
Religião e Moral (seja ela católica, evangélica ou outra qualquer), o 'outro' é sempre o que está do lado de lá de nossa crença, nunca um igual, mas simplesmente um tolerado (PINTO, 2005, p. 45).

Por outro lado, a imagem que o estudante e a pessoa comum têm das religiões vai sendo formada, ou melhor, fragmentada, pelos meios de comunicação, em particular a televisão. É necessário, afirma o autor, reintegrar a temática religiosa na escola à dinâmica social da construção do conhecimento, tirando-a do isolamento e da alienação que hoje a caracteriza, estando fechada em si mesma (PINTO, 2005, p. 44-45). Para tanto, faz-se necessário passar do ensino religioso ao ensino das religiões (PINTO, 2005, p. 48-50).

\section{França: laicidade, cidadania e ensino do fato religioso}

Se o problema do ensino religioso em Portugal se configura por meio da transformação de um país formado a partir de uma religião histórica, social (e, de alguma maneira, mesmo politicamente) hegemônica, confrontado com uma nova configuração social, agora marcada pela diversidade religiosa, o caso francês é notoriamente diferente. A república francesa se constituiu em oposição à tradição religiosa, ou melhor, como ruptura contra uma organização sócio-política que se fundamentava em uma perspectiva religiosa ${ }^{3}$. Nessa nova configuração sócio-política, é o conceito de laicidade que determina o caráter da vida pública francesa. Assim, não seria inadequado dizer que a república francesa se institui como uma organização sócio-política antirreligiosa (em substituição à ordem predominantemente religiosa do Antigo Regime) e se consolida como irreligiosa (no sentido de que a religião não seria uma voz válida na discussão pública) ${ }^{4}$. Portanto, ergue-se a grande questão: se a religião se torna um assunto privado, por que e como inserir a sua discussão no

\footnotetext{
30 processo de emancipação laica do Estado é descrito por GAUCHET, M. La religion dans la démocratie: parcours de la laïcite. Paris: Gallimard, 1998. p. 31-60. (Coleção Le débat).

4 Dito de outra maneira, a linguagem religiosa não tem, nesse contexto, validade na discussão pública.
} 
espaço da escola pública laica? Se a República da França se forma, desse modo, contra a tradição religiosa, como agora reencontrar a religião na escola laica? E de que modo?

É a esse desafio que o relatório elaborado por Régis Debray pretende elaborar as condições de uma resposta. Em 2002, atendendo a uma consulta do Ministério da Educação, Debray apresentou o relatório "O ensino do fato religioso na escola pública”, discutindo como justificar a presença do fato religioso na escola pública; quais as principais objeções, tanto do ponto de vista laico quanto do ponto de vista eclesiástico, a essa inclusão; como realizá-la; como situar o ensino do fato religioso diante do princípio da laicidade. O relatório é encerrado com algumas recomendações práticas ao Ministério para a implementação do ensino do fato religioso na escola pública francesa.

A primeira justificativa para o ensino do fato religioso vem de um aparente consenso social sobre a ideia de "reforçar o estudo da religião na escola pública” (DEBRAY, 2002, p. 3). Esse consenso se deveria não apenas à "atualidade traumatizante" (provavelmente referindo-se à equação que iguala terrorismo e fundamentalismo; afirmação de identidades étnicas e intolerância), mas ao reconhecimento da necessidade de "uma aproximação racional das religiões como fato de civilização" (DEBRAY, 2002, p. 3).

O estudo das religiões integra o desafio da manutenção da herança cultural e civilizacional europeia, a preservação da memória coletiva. Por outro lado, o estudo das religiões integra o desafio de oferecer elementos para a educação de uma cidadania preparada para o convívio com diferenças étnicas e culturais que se manifestam em diferenças religiosas.

Do lado propriamente pedagógico, o reconhecimento do enfraquecimento ou mesmo esfacelamento dos meios tradicionais de comunicação e educação: família, igreja, enfim, a comunidade, no sentido tradicional, já não mais é a grande educadora; esta perde terreno, a passos largos, para os media, máquina de produzir signos - e também de desarticular significados, reduzindo-os a um vórtice de informações, de imagens que, embora se sucedam, parecem condenar o "espectador" a viver em um eterno presente; sem passado, sem porvir. Antes do estabelecimento do Establishment - dos media, pretendeu se transferir da família para a escola, da comunidade para a República a tarefa da formação educacional; no presente momento, no entanto, as "disciplinas do sentido" (literatura, 
filosofia, história, arte) não gozam de prestígio em um mundo que se acostumou a seguir a dinâmica do videoclipe.

O problema da incultura religiosa articula-se em outro, muito maior: o da incultura stricto sensu. O interesse do educador não se dirige à religião em si mesma, mas, sim, à sua importância para a compreensão do processo civilizacional:

não se trata de recolocar "Deus na escola", mas de prolongar o itinerário humano por vias múltiplas, pelo que a continuidade cumulativa, que se chama cultura, distingue nossa espécie de outras, menos mutáveis. Tradições religiosas e porvir das Humanidades estão no mesmo barco. Não se reforçará o estudo do religioso, enquanto não se reforçar o estudo como um todo (DEBRAY, 2002, p. 5, grifo no original).

A pertinência educativa da história das religiões está em permitir rearticular as origens civilizacionais, assumindo a perspectiva da longa duração. A diferença está em que o que nos acostumamos a chamar de incultura dos jovens é, na verdade, outra cultura, uma "cultura de extensão":

ela dá prioridade ao espaço sobre o tempo, ao imediato sobre o permanente, tirando desta a melhor parte das novas ofertas tecnológicas [...]. Alargamento vertiginoso dos horizontes e retraimento drástico das cronologias. Contração planetária e pulverização do calendário. Se des-localiza tanto que se "des-historiza" (DEBRAY, 2002, p. 5-6).

Resgatar a história das religiões é contribuir para corrigir o desequilíbrio presente entre espaço e tempo:

constatando que o acontecimento (digamos: as Torres Gêmeas) não manifesta seu relevo e sua significação, se não na profundeza do tempo, ela pode contribuir para relativizar entre os estudantes a fascinação conformista da imagem, a peste publicitária, a taquicardia informativa, dando-lhes meios suplementares de escapar do presente-prisão, para fazer voltar, mas em conhecimento de causa, ao mundo de hoje. Encontramo-nos distantes de um projeto híbrido de "rearmamento moral", de uma garantia espiritual mínima ou de uma nostalgia benevolente e meramente patrimonial (DEBRAY, 2002, p. 6, grifo no original). 
Debray encontra nas chamadas disciplinas do sentido as principais responsáveis pela inclusão e discussão do fato religioso na escola. A seguir, temos uma síntese da abordagem própria de cada uma dessas disciplinas quanto ao fato religioso, deixando claro que, no esquema proposto pelo autor, essas abordagens não são hierarquizadas:

- Letras e línguas: fazer compreender os diferentes modos e estratégias de discurso;

- Filosofia: explicitar a diferença entre uma relação mágica, racional ou religiosa com o mundo;

- Ensinamentos artísticos: os estudos das formas dos símbolos e de suas representações confrontam necessariamente as culturas religiosas;

- História e Geografia: a organização do mundo contemporâneo é ininteligível sem se fazer referência às estruturações religiosas das culturas (DEBRAY, 2002, p. 7).

O que antecipa a ideia fundamental que veremos à frente: o estudo das religiões não é exclusividade de uma disciplina, embora não se deslegitime $a$ priori uma disciplina a ser chamada "história das religiões". Veremos agora as objeções práticas apontadas pelo relator à inclusão desta nova disciplina.

A essas objeções Debray chama "cavalos de Troia" consistindo, basicamente, em dois modos de crítica. De um lado, laico, a advertência quanto ao risco da instrumentalização desse ensino para fins de proselitismo, o temor da subordinação do racional (a escola, a ciência) ao irracional (a fé, a magia, a igreja). Do lado eclesiástico, ou crente, a ameaça do relativismo, a decomposição do sagrado, do totalmente outro, do mistério profundo e tremendo em análises reducionistas de cunho histórico, econômico e sociológico (DEBRAY, 2002, p. 7-8).

A base da réplica do relator às objeções laicas e confessionais encontra-se na seguinte afirmação: "o ensino do religioso não é um ensino religioso" (DEBRAY, 2002, p. 9). Tal réplica desdobra-se em seis pontos: primeiro, a necessidade de distinguir a aproximação do fato religioso como objeto de estudo, de conhecimento, em relação à religião como objeto de culto e como ato de fé; segundo, a discussão sobre a "questão do sentido" não invalida 
nem proíbe o tratamento escolar da religião, porque essa discussão, sobre o fundamento da realidade, não é uma exclusividade das religiões, mas é colocada, também, no plano filosófico, artístico e mesmo científico; terceiro, a exclusão do ensino do fato religioso do monopólio e do controle estatal do conhecimento favorece a irracionalidade e o fanatismo, a intolerância e a violência simbólica e física; quarto, o saber e testemunho não se invalidam, a aproximação "objetivante" e a aproximação "confessional" podem existir e prosperar simultaneamente. É preciso distinguir entre o religioso como objeto de cultura e o religioso como objeto de culto; quinto, a suspensão do juízo ${ }^{5}$ por parte dos docentes é condição para todo tipo de ensinamento, e não apenas para o ensino sobre religiões; sexto, a sociedade se encontra diante de uma época marcada pela incultura em geral e por uma particular incultura religiosa, que afeta não apenas os estabelecimentos de ensino públicos, mas as próprias instituições religiosas, aí incluídos os estabelecimentos confessionais de ensino (DEBRAY, 2002, p. 9-15).

Então chegamos ao ponto mais crítico da discussão: como realizar a inclusão do ensino do fato religioso na escola laica? É nesse momento que Debray descarta a possibilidade de inclusão de uma nova "matéria" escolar, levando em conta tanto a precaução laica (contra a ameaça de utilização do espaço público escolar com intenções prosélitas) quanto o próprio reconhecimento da saturação que caracteriza atualmente o sistema escolar. Desse modo, considera que a legitimidade da história das religiões no Ensino Superior e na pesquisa, não leva, imediatamente, à afirmação de sua inclusão como disciplina específica na educação básica. Pesam sobre a escola vários problemas; podemos dizer: disciplinas demais, tempo de menos, e mesmo a incompetência para lidar com a diversidade dos estudantes. Introduzir a história das religiões como mais uma disciplina seria condená-la a um lugar secundário (DEBRAY, 2002, p. 16-17).

\footnotetext{
5 Evidentemente, esse não é o lugar para resgatar a história da noção de “suspensão do juízo", e todas as suas implicações teóricas e filosóficas; mas convém salientar o uso, na Ciência da Religião, da postura conhecida como "ateísmo metodológico" ou "agnosticismo metodológico", esta mesma dependente da suspensão de juízo (FILORAMO, G.; PRANDI, C. As ciências das religiões. São Paulo: Paulus, 1999. p. 21-22; FRANKE, E.; PYE, M. The study of religions and its contribution to problem-solving in a plural world. Marburg Journal of Religion, v. 9, n. 2, 2004. Disponível em: <http://archiv.ub.uni-marburg.de/mjr/art_franke_2004.htm>. Acesso em: 25 out. 2001).
} 
Fosse instituída a disciplina, pergunta-se: quem estaria habilitado a lecioná-la? Esta seria confiada aos egressos da Faculdade de Teologia? E erguem-se outros problemas práticos, como a inexistência de concursos de ingresso no magistério para uma disciplina que até o momento não existia. Daí, o relator vislumbrar na preparação dos professores e dos próprios programas das disciplinas para tratar a questão religiosa como a solução mais pragmaticamente eficaz e mais social e politicamente aceitável, sem causar maiores transtornos (nem gastos) para o Estado (DEBRAY, 2002, p. 17).

O ponto de Arquimedes da proposta de Debray se encontra na afirmação da necessidade de articular os graus superiores de pesquisa e a prática docente na educação básica. Antes de se definir o que deve ser ensinado nas escolas, a questão fundamental está em como preparar adequadamente os docentes para esse desafio (DEBRAY, 2002, p. 17-18). Tal questão é enfrentada na seção V do relatório, "Quais recomendações?", na qual Debray oferece 12 propostas sobre o ensino do fato religioso. A primeira delas é dirigida à escola: refere-se à necessidade de conhecer as dificuldades de estudantes e professores para, a partir daí, poder elaborar planos de ação adequados às condições reais das escolas (DEBRAY, 2002, p. 25); a esta se seguem recomendações práticas para o ensino nos diferentes níveis escolares, proposições 2, 3 e 4 (DEBRAY, 2002, p. 2527); as proposições seguintes, de 5 a 12 , referem-se, todas, ao processo de formação docente, desde a formação inicial até as condições de formação contínua (DEBRAY, 2002, p. 27-34).

\section{A busca de um paradigma para o ensino religioso}

Tanto o livro de Pinto, ao oferecer o estado atual da Ciência das Religiões em Portugal, quanto o relatório de Debray, têm em comum a preocupação com a maneira como a discussão religiosa deve estar presente na escola básica. As soluções imediatas que apresentam são evidentemente diferentes, por atenderem a contextos político-sócio-educacionais também distintos. Em Portugal, diante de uma organização curricular do Ensino Médio que inclui uma disciplina chamada Educação Moral e Religiosa, de caráter confessional e na prática sob o controle das instituições 
religiosas, temos a proposta de uma nova disciplina, integrada ao currículo, e não um mero apêndice, a ser chamada História das Religiões. Na França, diante da inexistência de uma disciplina específica que trate a temática religiosa e, apresentadas e discutidas as objeções teóricas e as dificuldades práticas para sua implantação, considera-se como melhor alternativa, graças às condições atuais do ensino francês, a introdução do ensino do fato religioso em disciplinas já consolidadas no currículo, em especial as chamadas disciplinas do sentido (Letras e Línguas, Filosofia, Artes) e História e Geografia, cada uma delas tratando-o a partir de sua dinâmica própria.

No entanto, podemos encontrar na noção de cultura o fundamento comum que unifica essas propostas tão diferentes. A religião, tanto na proposta de Pinto quanto na de Debray, não é compreendida em perspectiva religiosa, a partir de si mesma. Não é colocada como objeto de fé, mas como objeto de conhecimento. Sua inclusão como tema dos currículos escolares não visa, de modo algum, à formação religiosa dos estudantes; esse aspecto continua, modernamente, restrito às opções privadas dos estudantes e de seus responsáveis. A intenção é atender à formação cultural e intelectual dos estudantes, visando, por fim, à sua formação como cidadão, oferecendo-lhes os elementos necessários para atuar social e politicamente. O estudo das religiões, ou o estudo do fato religioso, é compreendido como condição necessária dessa formação.

Diante desse quadro, podemos vislumbrar os elementos básicos que apontam para a constituição - evidentemente ainda em curso - de um paradigma para o ensino religioso. Esse paradigma leva em conta que o Ensino Religioso, ou, como parece soar melhor, o ensino das religiões, não se restringe ao problema de como o Estado e a educação pública lidam com a religião, mas se inscreve em algo muito maior, que é o problema da educação tout court; o grande desafio da educação atual - e não apenas nos contextos europeus a que nos referimos aqui - foi muito bem colocado por Debray. Trata-se de conciliar duas culturas: a cultura atual, fortemente associada com os jovens, em que a perspectiva do tempo é praticamente desconsiderada, uma cultura do gozo, voltada para o proveito, principalmente daquilo que é propiciado pela tecnologia. Acompanhado disto, vemos que essa cultura é marcada por uma forte fragmentação, propiciada pelos media e sua capacidade de produzir e divulgar signos e imagens de maneira contínua e vertiginosa, 
sem dar a oportunidade de se elaborar adequadamente a sua significação; ao mesmo tempo, as ferramentas tecnológicas e os media podem ser entendidos como os grandes educadores do tempo de agora. Assim, as estruturas tradicionais de formação e ensinamento se encontram em xeque; a crise não é (apenas) das religiões e do ensino religioso; a crise se refere, sobretudo, às condições de possibilidade da transmissão de conhecimento. A formação, cidadã e intelectual, do estudante terá de levar em conta não apenas aquilo que lhe propicia satisfação imediata - e nisto os artefatos tecnológicos e os media lhes têm atendido plenamente - mas é preciso oferecer os instrumentos conceituais que lhe propiciem as condições para interagir num mundo cada vez mais plural (por exemplo, no sentido de que se é obrigado a conviver com pessoas das mais variadas confissões religiosas e outras tantas irreligiosas) e em que grandes problemas mundiais se referem a discussões religiosas. Desse modo, o interesse em propiciar ao estudante - a todos os estudantes - conhecimentos os mais completos e rigorosos possíveis sobre as religiões não atende a um propósito particular, de formação religiosa pessoal - esse interesse, quando existe, continua sendo uma questão privada de cada um - mas diz respeito ao oferecimento das condições para que o estudante possa intervir, social e politicamente. Enfim, o ensino das religiões, ou o ensino do fato religioso, atende a necessidades públicas, intelectuais, sociais e políticas de formação e de conhecimento, e não a necessidades privadas e confessionais, para onde se volta o Ensino Religioso.

Ainda no plano internacional, a necessidade de um ensino das religiões que supere os paradigmas confessionais de ensino religioso pode ser encontrada em duas posições intelectuais em princípio bastante distintas: a da Ciência da Religião e a da Teologia. Edith Franke e Michael Pye, ao considerarem as relações entre a Ciência da Religião e a educação religiosa, afirmam:

desde que o estudo das religiões leva em conta a pluralidade de religiões, que é uma importante feição da sociedade moderna, ele deve ser considerado como um importante parceiro na construção de programas de educação religiosa, especialmente no domínio civil; cada programa deve incluir úteis referências informativas a várias religiões que são importantes na comunidade em questão. Quando plenamente desenvolvidos, eles podem se aproximar do ideal de "educação religiosa integrativa" (FRANKE; PYE, 2004). 
Embora os autores não explicitem em seu texto o que consideram uma educação religiosa integrativa, fica evidente, mediante a referência à pluralidade de religiões, que a educação religiosa vai além da formação a respeito da própria religião, estando de acordo, portanto, com as propostas de Pinto e Debray. Nessa direção, é interessante atentar para o que diz Paul Knitter, quanto ao diálogo inter-religioso:

[...] muitas pessoas de fé estão despertando para uma nova maneira de compreenderem a si mesmas. Nas diversas religiões, cada vez mais intensamente os fiéis sentem o desafio de encontrar e desenvolver suas identidades pessoais dentro da comunidade mais ampla de outras religiões. Para ser cristão ou hindu, a pessoa tem de fazer parte dessa comunidade religiosa mais ampla. Hoje em dia, assim parece, é preciso ser religioso inter-religiosamente (KNITTER, 2010, p. 29).

A afirmação de Knitter, embora seja motivada por outros interesses, no caso, se dirige prioritariamente às pessoas de fé. Não deixa de ser importante para compreendermos o que estamos chamando aqui de paradigma em desenvolvimento para o ensino religioso, ao revisar e superar o entendimento tradicional de que somente o conhecimento sobre a própria filiação religiosa é suficiente. Se, no decorrer de nossa exposição, salientamos a necessidade do conhecimento sobre as religiões para o convívio social e a formação intelectual dos estudantes, Knitter, enquanto teólogo, acrescenta um aspecto não menos importante: em uma sociedade plural, o autoconhecimento religioso precisa também levar em consideração o conhecimento sobre as demais religiões.

Dessa maneira, podemos concluir, embora preliminarmente, que o paradigma do ensino religioso em elaboração pode conciliar duas demandas igualmente importantes: se a primeira preocupação de uma educação pública está voltada para a formação intelectual e o exercício pleno da cidadania - e aqui entendemos que esta não se pode restringir à escola pública, mas devemos nos referir à formação educacional, realize-se em estabelecimentos públicos ou privados, confessionais ou não, que tenham o compromisso de formar pessoas habilitadas a interagir socialmente esta não pode ignorar os anseios e conflitos pessoais de seus estudantes, e o conhecimento sobre as diferentes religiões pode também contribuir 
para subsidiar os jovens em suas escolhas, livres e autônomas. Enfim, a discussão sobre o ensino religioso, na medida em que se situa no contexto da discussão sobre a educação em geral, pode colaborar para o enfrentamento da esquizofrenia que a educação parece ainda não saber lidar: formam-se agentes sociais, mas estes agentes sociais são pessoas singulares, e a relação entre o social e o individual não pode ser negligenciada.

\section{Olhando para o ensino religioso no Brasil}

Para ajudar a compreender a situação atual do ensino religioso no Brasil, podemos recolher dos casos português e francês, inicialmente, dois aspectos que, embora diversamente, também encontramos por aqui. De um lado, historicamente, a presença de uma religião hegemônica, marcando a compreensão comum (e mesmo legal) do que é religião, e se fazendo sentir, ainda que subliminarmente, se não na descrição legal do ensino religioso, em sua prática. Do ponto de vista teórico-metodológico e didático do Ensino Religioso, essa postura pode ser identificada com os modelos de ensino catequético e teológico, descritos por Passos (2007, p. 56-64; SOARES, 2009, p. 118-123). Essa primeira situação nos aproxima histórica, social e culturalmente, da experiência portuguesa. $\mathrm{O}$ segundo aspecto, de um sistema educacional leigo, no qual a discussão religiosa foi ignorada, justificando-se para isso a laicidade do Estado e a separação entre este e as confissões religiosas. Ainda que em síntese grosseira, estamos diante do caso francês, que apresenta aspectos também próximos à situação brasileira. Porém podemos introduzir aqui uma distinção: enquanto, na França a rejeição do ensino religioso se deu graças à oposição entre público e privado, racionalidade e crença, numa evidente desvalorização desta última, no contexto brasileiro, mais do que uma rígida separação epistemológica e política entre o público e o privado, entre a racionalidade e a não racionalidade, as propostas de exclusão da temática religiosa do ensino público se baseariam numa postura pragmática, de rejeição de um suposto "proselitismo" subvencionado pelo Estado (o que pode ser novamente aproximado da perspectiva portuguesa, pós-revolução de 1974). 
As obras de Passos (2007) e Soares (2010) configuram uma proposta de ensino religioso a partir do paradigma da Ciência da Religião. Passos inicia justamente pela discussão dos modelos de ensino religioso existentes em nosso país, e apontando as insuficiências dos modelos fundamentados em uma perspectiva confessional ou que no máximo consegue se estender ao ecumenismo cristão (PASSOS, 2007, p. 50-64; SOARES, p. 120-123). A base epistemológica necessária para um ensino religioso adequado à diversidade social e religiosa presente não pode mais ser encontrada nos esquemas tradicionais de transmissão do conhecimento religioso (interno), mas deve considerar os padrões de excelência na produção do conhecimento sobre as religiões, além, evidentemente, do problema técnico-didático de como tornar esse conhecimento acessível ao estudante. Dessa maneira, a proposição de Soares (2010, p. 118-127), de tratar o ensino religioso não como uma área de conhecimento autônoma (o que levaria a afirmação de que seus conteúdos seriam determinados pelas instituições religiosas, reconduzindo aos modelos catequético e teológico), mas como "resultado prático da transposição didática do conhecimento produzido pela Ciência da Religião" (SOARES, 2010, p. 118) nos mostra o que há de mais próximo ao ideal de um ensino religioso que se integre plenamente no processo formativo dos estudantes. E aqui nos permitimos discordar, ou melhor, ir além, quando o autor conclui o parágrafo dizendo: "para as aulas do ensino público, fundamental e médio", pois tal posição implicaria uma defasagem entre o estudante das instituições públicas e os das demais (confessionais, sobretudo), estes últimos privados de um conhecimento, que, conforme temos argumentado, se mostra social e intelectualmente necessário; além disso, introduz uma modificação político-jurídica em uma questão que deve ser tratada em termos didáticos e epistemológicos; um modelo de ensino religioso público e científico para a escola pública e outro, defasado por não atender às necessidades atuais de conhecimento, para as demais. É necessário superar a bifurcação com que se tem tratado o ensino religioso no Brasil, para que a legislação ${ }^{6}$ e a prática

\footnotetext{
6 A respeito do tratamento legal do ensino religioso no Brasil, consultar JUNQUEIRA, S.; CORREA, R. L. T.; HOLANDA, Â. M. R. Ensino religioso: aspecto legal e curricular. São Paulo: Paulinas, 2007. (Coleção Temas do ensino religioso).
} 
docente atendam as necessidades de conhecimento dos estudantes e não apenas as conveniências das instituições.

\section{Considerações finais}

O estado atual da discussão internacional e nacional sobre o ensino religioso nos coloca diante da constatação de que um novo paradigma para o ensino religioso encontra-se em constituição. Esse paradigma tem por base não mais as prioridades das confissões religiosas, com o intuito de produzir um ensino que seja autoimagem da religião com vistas à formação religiosa de seus adeptos, mas a Ciência da Religião, e isto não somente por razões epistemológicas estritas, mas em virtude da necessidade de atender plenamente a formação intelectual e social dos estudantes. Dessa maneira, é correto afirmar que o ensino religioso somente pode ter lugar nos sistemas de ensino, públicos principalmente, na medida em que ele se insere na preocupação mais ampla da formação dos estudantes, e não como uma disciplina desvinculada do restante da organização curricular. Por outro lado, isto nos leva a afirmar que o ensino religioso, nesses novos moldes, não pode se restringir às escolas públicas, porque não se pode legitimamente privar os estudantes das redes privadas e mesmo confessionais de ensino de um conjunto de conhecimentos social e epistemologicamente necessários em sua formação. Além disso, o conhecimento sobre as religiões pode propiciar, aos estudantes, um repertório que lhe permita não apenas interagir socialmente com pessoas que possuem uma visão religiosa diferente da dela, colaborando assim para a aceitação da diversidade e a superação do preconceito, oferecendo elementos para que se possa ir da mera tolerância ao efetivo e mutuamente enriquecedor convívio, mas também lhe subsidia em suas indagações pessoais, de ordem existencial e religiosa. Por fim, reconhecemos que o caminho a ser percorrido ainda é longo, e que a aproximação daquilo que está acontecendo fora do Brasil pode nos ajudar a enxergar melhor nossas deficiências neste campo, mas também a reconhecer e aprimorar nossos avanços. 


\section{Referências}

DEBRAY, R. L'enseignement du fait religieux dans l'École laïque. 2002. Disponível em: <http://www.ladocumentationfrancaise.fr/rapports-publics/024000544/ index.shtml $>$. Acesso em: 25 out. 2001.

FILORAMO, G.; PRANDI, C. As ciências das religiões. São Paulo: Paulus, 1999.

FRANKE, E.; PYE, M. The study of religions and its contribution to problem-solving in a plural world. Marburg Journal of Religion, v. 9, n. 2, 2004. Disponível em: <http://archiv.ub.uni-marburg.de/mjr/art_franke_2004.htm>. Acesso em: 25 out. 2001.

GAUCHET, M. La religion dans la démocratie: parcours de la laïcite. Paris: Gallimard, 1998. (Coleção Le débat).

KNITTER, P. F. Introdução às teologias das religiões. São Paulo: Paulinas, 2010. (Coleção Kairós).

JUNQUEIRA, S.; CORREAA, R. L. T.; HOLANDA, Â. M. R. Ensino religioso: aspecto legal e curricular. São Paulo: Paulinas, 2007. (Coleção Temas do ensino religioso).

PASSOS, J. D. Ensino religioso: construção de uma proposta. São Paulo: Paulinas, 2007. (Coleção Temas do ensino religioso).

PINTO, P. M. Para uma ciência das religiões em Portugal: cidadania \& cultura. Lisboa: Universitárias Lusófonas, 2005.

SOARES, A. M. L. Religião \& educação: da Ciência da Religião ao ensino religioso. São Paulo: Paulinas, 2010. (Coleção Temas do ensino religioso).

Recebido: 18/12/2010

Received: 12/18/2010

Aprovado: 23/07/2011

Approved: 07/23/2011 